\title{
THE HAZEL GROUSE, BONASA BONASIA, IN TWO SAMPLE AREAS IN THE CARNIC ALPS (FRIULI-VENEZIA GIULIA, NORTH-EASTERN ITALY)
}

\begin{abstract}
A study on the Hazel Grouse, Bonasa bonasia, was carried out in the Carnic Alps in the period 2008-2010. The aims were to determine some parameters related to breeding activity and territoriality and to identify conservation actions in favour of the species. The results show a reduction of the area where the species is established compared to the past and a distribution concentrated in favourable zones. Bonasa bonasia is losing territory especially in low mountain areas, in the outermost Alpine river valleys and in the Prealps. Abandonment of traditional agricultural, silvicultural and pastoral activities, habitat fragmentation and anthropization are among the main causes of this situation. Finally, some measures aimed at reversing the tendency to rarefaction and the related problems are reported.
\end{abstract}

Key words - Bonasa bonasia, breeding parameters, rarefaction, conservation measures, Carnic Alps.

Riassunto - Il Francolino di Monte, Bonasa bonasia, in due aree campione delle Alpi Carniche (Friuli-Venezia Giulia).

Nel periodo 2008-2010, sulle Alpi Carniche, è stata effettuata una ricerca sul Francolino di monte, Bonasa bonasia, mirante a determinare alcuni parametri legati all'attività riproduttiva e alla territorialità e ad individuare azioni finalizzate a favorire la specie. I risultati ottenuti hanno evidenziato una riduzione dell'area in cui il taxon è insediato rispetto al passato ed una distribuzione concentrata in zone favorevoli. Ł̀ inoltre emerso che il tetraonide sta perdendo territorio soprattutto in bassa montagna, nelle valli alpine più esterne e sulle Prealpi. Abbandono delle tradizionali attività agrosilvopastorali, frammentazione dell'habitat e antropizzazione sono state individuate fra le principali cause di tale situazione. Infine sono riportate alcune misure finalizzate ad invertire la tendenza alla rarefazione e le problematiche connesse.

Parole chiave - Bonasa bonasia, parametri riproduttivi, rarefazione, misure conservative, Alpi Carniche.

(*) Via Udine, 9 - I-33028 Tolmezzo (UD). E-mail: itassar@tiscali.it 


\section{Introduction}

The Hazel Grouse, Bonasa bonasia, is a polytypic galliform with Eurosiberian boreoalpine distribution. In Italy, it is distributed in a fairly regular manner in the Alps from the Ossola Valley (Piedmont) to the Julian Prealps (Friuli); it is missing in most of the Western Alps, where it likely disappeared in the $19^{\text {th }}$ century (ARRIGONI DEGLI ODDI, 1929; De Franceschi, 1992 and 1994). The Italian distribution area was more extensive in the past, including the entire Alpine arch (DE Franceschi, 1994). The Ossola and Sesia valleys were recolonized in the 1940s and 1980s respectively (RUsCetTa, 1946; Moltoni, 1951; Bordignon \& Pescarolo, 1990). The species underwent a strong, progressive rarefaction in the second half of the $20^{\text {th }}$ century throughout the Alpine range and in much of the Western Palaearctic Region (CRAMP \& Simmons, 1980; De Franceschi, 1992). In the Carnic Alps, this tetraonid suffered a 65-70\% decline in the period 1955-1987 (De FrancESCHI, 1992). The most common limiting factors are: environmental changes deriving from the abandonment of traditional agricultural activities, biotope destruction, harsh weather conditions during the breeding season, disturbance due to tourism and various forms of forest resource exploitation, hunting, poaching and predation (DE FRANCESCHI, 1992 and 1994).

The aims of the present study were to determine some parameters related to breeding activity and territoriality and to identify possible conservation actions in favour of the species.

\section{Study areas and methods}

Social dynamics from the end of World War II to the present have had a sudden, marked effect on the Alpine environment, causing changes that have impacted the habitats of various species. Because of its particular environmental preferences, Bonasa bonasia has suffered greatly from such habitat alterations. Therefore, two areas monitored by the author in the past were selected to acquire information necessary for a temporal comparison. Both areas are in the Carnic Alps and cover ca. 80 ha.

The first area (Socleif) lies between 400 and $750 \mathrm{~m}$ a.s.l. in the municipality of Socchieve. The variability of exposure, slope and morphology, also due to some very small valleys, as well as different management practices, have led to the co-existence of a wood at various developmental stages, abandoned meadows colonized by shrubby vegetation (especially Hazel, Corylus avellana, but also Blackberry, Rubus fruticosus), clearings and some marginal meadows still used for haymaking and occasional pasturing. The wood consists of Beech, Fagus sylvatica, Chestnut, Castanea sativa, Sessile Oak, Quercus petraea, Scots 
Pine, Pinus sylvestris, Hazel, Willows, Salix spp., Hornbeam, Carpinus betulus, Spruce, Picea abies, Whitebeam, Sorbus aria, and Sycamore Maple, Acer pseudoplatanus, in varying percentages according to the sites. Some zones are dominated by monospecific formations, particularly of Fagus sylvatica and Pinus sylvestris. The wood is managed as high forest, and the density and structure are extremely variable. Timber harvesting is localized and of small magnitude. Owing to the disappearance of the last inhabitants of houses at the margins of the area and depopulation of nearby villages, agriculture, silviculture and pasturing have been progressively abandoned in the last few decades, with consequent expansion and ageing of the wood and the overgrowth of some clearings.

The second area (Dimpeç) extends between 1400 and $1650 \mathrm{~m}$ a.s.l. in the municipality of Ampezzo. It is represented by a disetaneous wood of Picea abies, Fagus sylvatica, and Silver Fir, Abies alba, plus European Larch, Larix decidua in some zones; the wood is managed as high forest, with a variable density and structure, clearings, ecotonal areas occupied by Raspberry, Rubus idaeus, Salix spp., Blueberries, Vaccinium spp., Rowan, Sorbus aucuparia, Red Elder, Sambucus racemosa, etc., and pastures on the margins. In the publicly owned forest district encompassing the area, the degree of timber harvesting varies and depends on the realization of wooded lots usually involving the felling of a few hundred $\mathrm{m}^{3}$ of lumber by specialized firms. The exposure is mainly $\mathrm{W}$ to $\mathrm{NW}$ and the mean slope is ca. 20\%. A recent expansion of the trail network and forest roads, particularly in zones nearest the only paved road in the vicinity, has only partially affected the area, even though it has increased the number of people who visit it.

The two areas are situated in altitudinal bands representing the lower and upper limits of the Bonasa bonasia breeding range in Friuli and strongly differing in various aspects; they were chosen to highlight possible differences.

The study was conducted from 2008 to 2010 . Three censuses were carried out each year in spring and autumn by means of acoustic stimulation, according to the methods reported by De FrANCESCHI (1984 and 1996) and Tосснетто (1993) using preset transects with 20 broadcasting stations at $150 \mathrm{~m}$ intervals. The type of contact was recorded as: response to the call, consisting of a sound contact (song or burr of the wings) or visual contact; spontaneous song; sighting not induced by stimulation. In summer, surveys were done by 5-7 beaters walking on a line 10-20 meters from each other to collect data on breeding success. Throughout the investigation, information on the species inside the areas was acquired by interviews with habitual and occasional visitors. The sample areas were also walked several times to define the territories more precisely, to identify possible frequented zones not recorded during the other types of surveys and to gather further data on breeding success. Particular attention was given 
to the finding of droppings and of tracks on snowy ground. All contacts were georeferenced. The areas of the territories were calculated by the minimum convex polygon method. The fieldwork was carried out by the author and some collaborators.

In addition to data directly attributable to Bonasa bonasia, information on the following aspects was collected: status of the frequented environments; presence of humans, dogs, cats, predators, ungulates; silvicultural operations, etc..

\section{Results}

In the Socleif area, the density was the same in 2008 and 2010 and reached its maximum in 2009. In the Dimpeç area, the highest value was recorded in the first year and remained stable in the following years (Tab. I). At Socleif, the number of males per $1000 \mathrm{~m}$ of transect length and per 100 broadcasting stations in both spring and autumn reached the maximum value in 2009, while the minimum was in spring 2010 and autumn 2008. At Dimpeç, the maximum obtained in 2008 decreased in 2009 and even more in 2010 in both spring and autumn (Tab. I). On average, the values were lower in autumn by $29 \%$ in the former area and by $22 \%$ in the latter. The area at lower altitude (Socleif) generally had higher values for both the single years and the means.

During the acoustic stimulation surveys in both areas, the most frequent type of contact with males in both spring and autumn was the response to the call, while the least frequent was spontaneous song (Tab. II). These two types of contacts were recorded mainly in spring, while

Table I - Summary of data obtained during the surveys $\left(\sigma^{\pi} \sigma^{\top} / 1000 \mathrm{~S}: \sigma^{\pi} \sigma^{\top} / 1000 \mathrm{~m}\right.$ of transect length in spring; $\sigma^{\top} \sigma^{\top} / 100 \mathrm{ST}$ S: $\sigma^{\top} \sigma^{\top} / 100$ broadcasting stations in spring; $\sigma^{\top} \sigma^{\top} / 1000 \mathrm{~A}$ :

$\sigma^{\pi} \sigma^{\pi} / 1000 \mathrm{~m}$ of transect length in autumn; $\sigma^{\pi} \sigma^{\top} / 100$ ST A: $\sigma^{\top} \sigma^{\top} / 100$ broadcasting stations in autumn).

Tabella I - Sintesi dei dati ottenuti durante i rilievi ( $\sigma^{\top} \sigma^{\top} / 1000 \mathrm{~S}: \sigma^{\top} \sigma^{\top} / 1000 \mathrm{~m}$ di percorso in primavera; $\sigma^{\top} \sigma^{\top} / 100$ ST S: $\sigma^{\top} \sigma^{\top} / 100$ stazioni di emissione in primavera; $\sigma^{\top} \sigma^{\top} / 1000$ A: $\sigma^{\top} \sigma^{\top} / 1000$ $m$ di percorso in autunno; $\sigma^{7} \sigma^{\top} / 100$ ST A: $\sigma^{7} \sigma^{\top} / 100$ stazioni di emissione in autunno).

\begin{tabular}{|c|c|c|c|c|c|c|c|c|}
\hline \multirow{2}{*}{$\begin{array}{l}\text { Sample area } \\
\text { Year }\end{array}$} & \multicolumn{4}{|c|}{ Socleif } & \multicolumn{4}{|c|}{ Dimpeç } \\
\hline & 2008 & 2009 & 2010 & Mean & 2008 & 2009 & 2010 & Mean \\
\hline Surface area (ha) & 80 & 80 & 80 & - & 80 & 80 & 80 & - \\
\hline Territories/100 ha & 3.75 & 5.00 & 3.75 & 4.17 & 3.75 & 2.50 & 2.50 & 2.92 \\
\hline$\sigma^{n} \sigma^{n} / 1000 \mathrm{~S}$ & 0.78 & 0.89 & 0.67 & 0.78 & 0.78 & 0.67 & 0.56 & 0.67 \\
\hline$\sigma^{\pi} \sigma^{\pi} / 100 \mathrm{ST} \mathrm{S}$ & 11.67 & 13.33 & 10.00 & 11.67 & 11.67 & 10.00 & 8.33 & 10.00 \\
\hline$\sigma^{x} \sigma^{x} / 1000 \mathrm{~A}$ & 0.44 & 0.67 & 0.56 & 0.56 & 0.78 & 0.44 & 0.33 & 0.52 \\
\hline$\sigma^{x} \sigma^{x} / 100$ ST A & 6.67 & 10.00 & 8.33 & 8.33 & 11.67 & 6.67 & 5.00 & 7.78 \\
\hline
\end{tabular}


in autumn it was easier to make sightings not induced by stimulation (Tab. II). Contacts with females were not included in Table II because of their low numbers; however, their percentage with respect to the total contacts (males plus females) was slightly lower in spring than in autumn (13\% vs $17 \%)$. In both spring and autumn, the frequency of contacts with females in response to the call was double that of sightings not induced by stimulation, while spontaneous singing was never heard during the acoustic stimulation surveys.

Some data on breeding biology were obtained, albeit for a small sample $(n=5)$. In the first part of summer, contacts were made with females with brood in 2009 and 2010 in the area in the municipality of Socchieve (ratio juveniles/brood respectively 7 and 8) and in 2009 in the other area (ratio juveniles/brood 6). In the second part of summer, females with brood were only contacted in 2009; the ratio juveniles/brood was 4 in the Socleif area and 3 in the Dimpeç area, with breeding success (no. juveniles/no. adult females) and mortality rate of 1.33 and $43 \%$ and 1.5 and $50 \%$, respectively.

The territory size was estimated at 7-10 ha for the Socleif area and 9-13 ha for the other area.

\section{Discussion}

The greater suitability of the Socleif area due to the site parameters, milder climate and higher environmental variability has favoured the presence of Bonasa bonasia, leading to higher values of the indices (Tab. I). Confirmation of this also comes from the smaller territories in the lower-altitude area. The territory size reported by various authors is extremely variable; comparison with the values obtained in the Alps shows that the values in the present study are similar to those reported by De Franceschi \& Osti (1982) for the Alba Valley (10 ha) and higher than those given by Tосснетто (1993) for the Cansiglio Forest (4-5.5 ha).

The density values, especially those in the Socleif area, are higher on average than those reported by DE FrANCESCHI (1992) for the CentralEastern Alps (1-1.2 to 2-3 pairs/100 ha) and by Tосснетто (1993) for the Cansiglio Forest (1.08 pairs/100 ha) but lower than those in rather limited areas (1 pair/10 ha, Incaroio Alps; De Franceschi, 1988). The density of 3 pairs/100 ha recorded in the Cellina Valley (Carnic Prealps) (Mattedi in De Franceschi, 1996) is similar to that in the Dimpeç area. Very variable values have been found in other zones of Europe and the densities in the present study fall within their range: 0.4 individuals $/ 100$ ha to 5 pairs/100 ha in France (Bernard-Laurent \& Magnani, 1994), 2.4 to 5.4 territories/100 ha in Bohemia (KLAUS, 1995), 5.3 pairs/100 ha and up to 8 pairs/100 ha in the Swiss Jura (ZBInden, 1979), 7-8 pairs/100 ha in the Alps of Haute Provence (Montadert, 2005). 
The number of males per $1000 \mathrm{~m}$ of transect length in both spring and autumn is lower than the values recorded in the Tarvisio Forest and in Carnia during the breeding period and at the end of summer (1.12) and in October in the Cellina Valley (1.27 and 1.7) (De Franceschi, 1996; Mattedi in De Franceschi, 1996).

The mean number of males per 100 broadcasting stations in spring is much higher than that reported by MONTADERT (2005) for the Alps of HauteProvence (2.18-4.54), while the maximum values are similar (Carnic Alps: 13.33; Alps of Haute-Provence: 13.8). The high discrepancy in the mean values is probably due to the fact that the surveys in Haute-Provence were conducted in larger areas whose suitability was consequently lower, as confirmed by the absence of contacts in some years.

The results of the acoustic stimulation censuses in spring (Tab. II) agree with those of MonTADERT (2005) concerning the most and least frequent types of contact, while the percentage of response to the call and the percentage of sighting are respectively higher (61.51 vs 45$)$ and lower (28.17 vs 41$)$.

With respect to the population size, the values obtained from the summer censuses, although generally within the range reported by other authors (Cf. e.g. De Franceschi, 1992), seem to indicate an unfavourable situation given the limited number of broods contacted.

The situation of Bonasa bonasia in the Socleif area has been known by the present author since the 1980 s, while the first contacts date to the preceding decade. The comparison with previous data indicates substantial stability of the population in the past 20 years (notwithstanding the variability that can be recorded from year to year). However, the density was higher until about the end of the decade prior to that, i.e. at least 5-6 pairs/100 ha (Rassati, pers. obs.); moreover, in the same period, at least 2-3 broods were found each year, even in the second part of summer (Rassati, pers. obs.). The finding of broods in the $1950 \mathrm{~s}-60 \mathrm{~s}$ was also common (Rassati G., in verbis). In the Dimpeç area, investigations by the present author in the second half of the 1990s showed similar densities whereas at least one brood was usually contacted each year (Rassati, pers. obs.).

Table II - Percentage frequency of contact types (See "Study areas and methods") with males during the acoustic stimulation censuses (total data).

Tabella II - Frequenza percentuale dei tipi di contatto (Vedi "Aree di studio e metodi") con maschi ottenuta durante $i$ censimenti mediante stimolazione sonora (dati complessivi).

\begin{tabular}{c|c|c}
\hline Contact type & Spring & Autumn \\
\hline Response to call & 61.51 & 58.57 \\
\hline Spontaneous song & 10.32 & 6.90 \\
\hline Sighting & 28.17 & 34.52 \\
\hline
\end{tabular}


The substantial stability of densities in the past 20 years is probably due to several related factors: the strong decline of the species had occurred previously (DE FranceschI, 1992); the habitat suitability has remained similar in the last few decades since there have been no significant changes in the Dimpeç area while in the other area the decrease of silvicultural operations has been countered by the abandonment of some agricultural zones, and thus the reduced environmental suitability of the forested areas has been compensated by the increased suitability of marginal zones preferred by the species; human disturbance has not varied substantially, even though the expansion of forest roads and trail network in the area in the municipality of Ampezzo has increased the number of visitors (also those with dogs), who very probably have reduced the ability to contact broods, which are very sensitive to anthropogenic disturbances: contacts occurred mainly in zones far from forest roads, particularly in the second part of summer when the area is subjected to a "tourism flow".

The results of this study must be considered positive in that they indicate that Bonasa bonasia is still present with vital populations in some zones. Nevertheless, the selected areas are among the best in the respective altitudinal bands and are relatively small. Therefore, albeit with some limitations due for instance to the elevation of the Dimpeç area or the change of forest structure in the lower-altitude area, the reference densities should tend toward those found in similar situations, i.e. approximately 1 pair/10 ha (Incaroio Alps; De FrancESCHI, 1988). This value was also indicated by MonTADERT (1995) as representative in the presence of an optimal habitat. Therefore, the sample areas must be considered islands favourable to the species inside vaster zones where it is rare or absent. This situation is confirmed by data from most areas examined by the present author, from Cadore to the Julian Prealps. As in those areas, the presence of suitable but unoccupied environments in the present sample areas suggests that the current densities are lower than the potential ones. The large-scale investigation has also shown that the species is absent from various zones where it was contacted in the past even with relatively high frequency, confirming what has already been found: the reduction of the area in which the species is established (DE Franceschi, 1988). The situation could become even worse in the next few decades, especially in low-altitude zones near villages characterized by small private properties, such as the Socleif area. Indeed, the effect of abandonment of agricultural zones will probably not balance the absence of silvicultural interventions, which is causing various woods to advance, grow old and assume a structure unfavourable to the tetraonid. This is proved by surveys conducted in agricultural areas not used since the 1960 s-80s, which were subsequently colonized by Bonasa bonasia but are now mostly abandoned (Rassati, pers. obs.). This represents the "closure" 
of a scenario suggested by DE FRANCESCHI (1984) who reported a numerical increase of the species in suitable environments of the Prealps and the piedmont band from the province of Sondrio to that of Udine thanks to the abandonment of cultivated areas, also writing: "It will be interesting to observe how long the increase of this tetraonid will continue in the newly or recently colonized territories." The cutting of more or less extensive areas inside the wood for hay was a common practice in the past in many mountain zones. This created a mosaic with a very high ecotonal index, permitting various species typical of open or ecotonal areas now missing in such zones to inhabit them (Rassati G., in verbis). For instance, in the Socleif area, a pair has always been found in the last 30 years near a zone that had been cut for hay until the 1960s (Rassati G., in verbis) but which subsequently became a clearing and today is gradually becoming a closed wood.

From the data collected in the sample areas and in most of the other investigated zones, it is evident that the species is losing territory (with rare exceptions), especially in low mountain zones, in the outermost Alpine valleys and in the Prealps where the positive effect of abandonment of agricultural areas is ending, and that the density is often lower than the carrying capacity. An attempt to reverse the tendency to rarefaction would require an integrated territorial management that takes into consideration, especially for the silvicultural aspects, what has emerged from various studies (Cf. e.g. Bergmann \& Klaus, 1994 and 1994a; Bernard-Laurent \& Magnani, 1994; De Franceschi, 1984, 1994a and 1996; De Franceschi \& Bottazzo, 1995; Klaus, 1995; Lieser et alii, 1995; Montadert, 2005; Montadert et alii, 1994; Suchant, 1995; Swenson, 1995; Swenson \& DANielsen, 1995; Tocchetto, 1994) and also involves measures similar to those reported, in a recent study in the Carnic Alps, for the Capercaillie Tetrao urogallus (RASSATI, 2009). The following aspects should be considered in particular: forest management that focuses on the needs of the species and provides for an impact assessment after silvicultural operations to provide elements useful to decide whether to calibrate or suspend them; the achievement of a higher degree of connectivity among fragments of suitable habitat via the realization of "corridors", also in view of the tetraonid's low dispersal capacity; regulation of tourism-recreational uses by limiting the influx of people, especially those with dogs and during the brooding and rearing period; limitation of new forest roads to the bare necessity, with prior assessment of whether the realization of roads would affect areas important for the species, especially in relation to the ease with which transit permits have been issued, also for various types of events that could have a strong impact; suspension of the realization and expansion of overhead electric and telephone lines and ski slopes and lifts; control of sporting activities, poaching and possible predators related to human settlements (cats, 
dogs). Although predators have had a "normal" impact in the sample areas (given the very few indirect evidence of predations such as carcasses or feathers found), this last factor is especially important in the low-altitude zones: in the past, part of the Socleif area was inhabited by feral cats (RASSATI, 2005). It was not possible to assess any interaction of ungulates (Red Deer, Cervus elaphus, Roe Deer, Capreolus capreolus, Wild Boar, Sus scrofa) with Bonasa bonasia even though they can have an impact in particular situations (Cf. e.g. Bergmann \& Klaus, 1994 and 1994a; MONTADERT et alii, 1994): in such a case, it would be advisable to adopt control and regulation provisions. Finally, it is necessary to conduct studies prior to and after the adoption of the indicated measures in order to increase the knowledge of the species and its response to the actions undertaken.

In theory, the realization of the above-mentioned actions is easier in publicly owned areas. In fact, it is currently impossible to manage privately owned areas not provided with any form of planning and strongly subdivided; moreover, in a future perspective, it would be very difficult to reach consensus with a large number of owners who often live far away from their places of origin. In practice, such actions are also difficult in public properties, since the change in the ways silvicultural operations are carried out with respect to the past (also due to the social degradation that has affected the mountain) and the permissiveness toward tree-felling firms (symptomized by the change of attitudes of public administrations and of forest management regulations) have compromised any attempt to change the current policies. Despite the presence of what has just been reported and of the current socio-economic conditions, I believe that in some zones where the situation is most favourable an attempt must be made to conserve and/or reconstitute the environment by promoting traditional agricultural-silvicultural-pastoral activities as part of pilot projects also aimed at investigating which habitats are mainly selected by the tetraonid and at testing silvicultural techniques suitable to the species. These initiatives could make use of various contributions, at present mostly distributed "indiscriminately", without selecting the aim, with the exception of the strictly financial one which, in a global mediumlong-term view, does not even bring an overall economic return. Thanks to the characteristics of Bonasa bonasia, the initiatives could also involve relatively small areas, thus maintaining the managerial complexity and costs at acceptable levels.

As previously reported for Tetrao urogallus (RASSATI, 2009), I believe that the problem regarding the possibility of legal hunting belongs to the past (De FrANCESCHI, 1984, 1986, 1988 and 1992) and has been definitively resolved.

In conclusion, it is necessary to consider that, unlike Tetrao urogallus which, although unknown to many, can be considered a flagship species, 
Bonasa bonasia does not enjoy this privilege on account of its particular characteristics. Moreover, the latter species has not been the subject of scientific interest to the same degree as other Alpine galliforms, also because of the greater difficulty in studying it. In recent years, at least in Italy, researchers who monitored the species in the wild could count it on the fingers of one hand in the best of hypotheses. It is hoped that this situation is not the prelude to oblivion, which would very probably be a death sentence for this small forest-dwelling grouse.

Acknowledgements - The author thanks all the collaborators and people who provided information useful for the study.

\section{REFERENCES}

Arrigoni Degli Oddi E., 1929 - Ornitologia Italiana - Hoepli, Milano.

Bergmann H.-H. \& Klaus S., 1994 - Distribution, status and limiting factors of hazel grouse (Bonasa bonasia) in central Europe, particularly in Germany. In: Restoration plans for some European galliformes: hazel grouse, capercaillie and black grouse - Part 2. Office national de la chasse - Paris, Gibier Faune Savage, Game and Wildlife, 11 (Special number Part 2): 5-32.

Bergmann H.-H. \& Klaus S., 1994a - Restoration plan for the hazel grouse (Bonasa bonasia) in Germany. In: Restoration plans for some European galliformes: hazel grouse, capercaillie and black grouse - Part 2. Office national de la chasse - Paris, Gibier Faune Savage, Game and Wildlife, 11 (Special number Part 2): 35-54.

Bernard-LaURent A. \& Magnani Y., 1994 - Statut, évolution et facteurs limitant les populations de gelinotte des bois (Bonasa bonasia) en France: synthèse bibliographique. In: Plans de restauration pour quelques galliformes européens: gelinotte, grand tétras, tétras-lyre et perdrix bartavelle - Tome 1. Office national de la chasse - Paris, Gibier Faune Savage, Game and Wildlife, 11 (Hors série Tome 1): 5-40.

Bordignon L. \& Pescarolo R., 1990 - Nidificazione di Francolino di monte, Bonasa bonasia, in Valsesia (Vercelli) - Riv. ital. Orn., 60: 192-194.

Cramp S. \& Simmons K.E.L. (eds.), 1980 - The Birds of the Western Palearctic. 2. Hawks to Bustards - Oxford University Press, Oxford.

De Franceschi P., 1984 - Tetraonidi. Caccia e conservazione - Quaderni UNCZA.

De Franceschi P., 1986 - Caratteristiche ambientali, fluttuazioni, densità e gestione delle popolazioni di tetraonidi sulle Alpi italiane. In: Dessì-Fulgeri F. \& Mingozzi T. (red.). Atti Seminario Biologia dei Galliformi - Arcacavata di Rende: 35-50.

De Franceschi P., 1988 - La situazione attuale dei Galliformi in Italia. Ricerche recenti o ancora in corso. Problemi di gestione e prospettive per il futuro. In: Spagnesi M. \& Toso S. (eds.). Atti del I Convegno nazionale dei Biologi della Selvaggina - Suppl. Ric. Biol. Selvaggina, XIV: 129-168.

De Franceschi P., 1992 - Francolino di monte Bonasa bonasia. Pp. 697-708. In: Brichetti P., De Franceschi P. \& Baccetti N. (a cura di). Fauna d'Italia, XXIX, Aves. I - Calderini, Bologna.

De Franceschi P.F., 1994 - Status, geographical distribution and limiting factors of hazel grouse (Bonasa bonasia) in Italy. In: Restoration plans for some European galliformes: hazel grouse, capercaillie and black grouse - Part 2. Office national de la chasse - Paris, Gibier Faune Savage, Game and Wildlife, 11 (Special number Part 2): 141-160.

De FrancEschi P.F., 1994a - Restoration plans for hazel grouse (Bonasa bonasia), black grouse (Tetrao tetrix) and capercaillie (Tetrao urogallus) in Italy. In: Restoration plans for some European galliformes: hazel grouse, capercaillie and black grouse - Part 2. Office national de la chasse - Paris, Gibier Faune Savage, Game and Wildlife, 11 (Special number Part 2): 207-215. 
De Franceschi P. F., 1996 - I Tetraonidi della Foresta di Tarvisio - Cierre Edizioni, Verona.

De Franceschi P. F. \& Bottazzo M., 1995 - Habitat characteristics of brood-rearing sites of Hazel Grouse Bonasa bonasia in the eastern Alps (Friuli-Venezia Giulia, Italy). In: Jenkins D. (ed.). Proc. $6^{\text {th }}$ intern. Grouse Symp., Udine (Italy) - WPA \& INFS: 101-105.

De Franceschi P. \& Osti F., 1982 - Francolino di monte Bonasa bonasia. In: Brichetti P. (red.). Atlante degli uccelli nidificanti sulle Alpi italiane. I - Riv. ital. Orn., 52: 13-15.

KLAus S., 1995 - Hazel Grouse in the Bohemian Forest - results of a 20-year study. In: JENKINS D. (ed.). Proc. $6^{\text {th }}$ intern. Grouse Symp., Udine (Italy) - WPA \& INFS: 27-33.

Lieser M., Eisfeld D. \& Mann S., 1995 - Evaluation of Hazel Grouse habitat in the Black Forest (southern Germany) and implications for habitat management. In: Jenkins D. (ed.). Proc. $6^{\text {th }}$ intern. Grouse Symp., Udine (Italy) - WPA \& INFS: 106-110.

Moltoni E., 1951 - La ricomparsa del Francolino di monte Tetrastes bonasia rupestris (Brehm) in Valle Sesia (Alpi Pennine) e nell'Ossola (Alpi Lepontine) - Riv. ital. Orn., 21: 123-124.

Montadert M., 1995 - Occupation de l'espace par des mâles de Gélinotte des bois (Bonasa bonasia) dans le Doubs (France) - Gibier Faune Sauvage, Game and Wildlife, 12: 197-211.

Montadert M., 2005 - Fonctionnement démographique et sélection de l'habitat d'une population en phase d'expansion géographique. Cas de la Gélinotte des bois dans les Alpes du Sud, France. Thèse - Université de Franche-Comté.

Montadert M., Desbrosses R., Huboux R., Léonard P. \& Bernard-Laurent A., 1994 - Plan de restauration pour la gelinotte des bois (Bonasa bonasia) en France. In: Plans de restauration pour quelques galliformes européens: gelinotte, grand tétras, tétras-lyre et perdrix bartavelle - Tome 1. Office national de la chasse - Paris, Gibier Faune Savage, Game and Wildlife, 11 (Hors série Tome 1): 41-62.

RAssati G., 2005 - Aspetti generali dei vertebrati della Val Tagliamento dalla confluenza del Rio Nero alla confluenza del Torrente Degano. In: Ferigo G. (a cura di). Enemonç Preon Raviei Socleif - Numero unico della Società Filologica Friulana: 125-156.

Rassati G., 2009 - Il Gallo Cedrone, Tetrao urogallus, in due aree campione delle Alpi Carniche (Friuli-Venezia Giulia) - Riv. ital. Orn., 79 (1): 49-57.

Ruscetta A., 1946 - Ricomparsa del Francolino di monte nell'Ossola - Riv. ital. Orn., 16: 25.

Suchant R., 1995 - Silvicultural measures for the improvement of grouse habitats in the Black Forest. In: JEnkins D. (ed.). Proc. $6^{\text {th }}$ intern. Grouse Symp., Udine (Italy) - WPA \& INFS: 121-125.

Swenson J.E., 1995 - Habitat requirements of Hazel Grouse. In: Jenkins D. (ed.). Proc. $6^{\text {th }}$ intern. Grouse Symp., Udine (Italy) - WPA \& INFS: 155-159.

Swenson J.E. \& DANielsen J., 1995 - Seasonal movements by Hazel Grouse in south-central Sweden. Proc. $6^{\text {th }}$ intern. Grouse Symp., Udine (Italy) - WPA \& INFS: 37-40.

Tосснетто G., 1993 - Il Francolino di monte Bonasa bonasia (Linnaeus) nella Foresta del Cansiglio. Rilievi ecologici. Tesi di laurea - Università degli studi di Padova, Facoltà di Agraria., Padova.

Tocchetto G., 1994 - Metodi di censimento del Francolino di monte (Bonasa bonasia L.). In: DE Franceschi P.F. (a cura di). Pianificazione e gestione delle risorse faunistiche - Ministero dell'Ambiente, Azienda Regionale delle Foreste del Veneto: 27-30.

ZBinden N., 1979 - Zur Ökologie des Haselhuhns Bonasa bonasia in den Buchenwäldern des Chasseral, Faltenjura - Ornithol. Beob., 76: 169-214. 